\title{
The insulin-like growth factor-1 and expression of its binding protein-3 in chronic hepatitis $\mathrm{C}$ and hepatocellular carcinoma
}

\author{
AGNIESZKA ADAMEK ${ }^{1}$, ALDONA KASPRZAK ${ }^{2}$, HANNA MIKOŚ $^{3}$, \\ WIESŁAWA PRZYBYSZEWSKA ${ }^{2}$, AGNIESZKA SERASZEK-JAROS ${ }^{4}$, ARKADIUSZ CZAJKA ${ }^{1}$, \\ KAROLINA STERZYŃSKA ${ }^{2}$ and IWONA MOZER-LISEWSKA ${ }^{1}$ \\ Departments of ${ }^{1}$ Infectious Diseases, ${ }^{2}$ Histology and Embryology, ${ }^{3}$ Pediatric Endocrinology and Diabetes, \\ and ${ }^{4}$ Clinical Pathomorphology, Poznan University of Medical Sciences, Poznan, Poland
}

Received March 11, 2013; Accepted April 16, 2013

DOI: $10.3892 /$ or.2013.2546

\begin{abstract}
The role of growth factors produced by the liver, including insulin-like growth factor-1 (IGF-1) and its main binding protein, IGF binding protein-3 (IGFBP-3), in hepatitis $\mathrm{C}$ virus (HCV)-associated carcinogenesis has only partially been recognized and there is not much data available on the local expression of IGF-1 and IGFBP-3 in chronic hepatitis $\mathrm{C}(\mathrm{CH}-\mathrm{C})$. Therefore, the aim of the present study was to evaluate the IGF-1 and IGFBP-3 serum levels and tissue expression in liver biopsies of $\mathrm{CH}-\mathrm{C}$ patients $(\mathrm{n}=37)$ and hepatocellular carcinoma (HCC) samples $(n=61)$ as related to age- and gender-matched control serum samples $(n=15)$ and healthy liver samples $(n=10)$. Serum concentrations of IGF-1 (S-IGF-1) and IGFBP-3 (S-IGFBP-3) were measured by the ELISA method. Tissue expression of proteins was detected using ABC immunocytochemistry and evaluated applying a spatial visualization technique. Concentrations of S-IGF-1 and hepatic expression of IGF-1 (H-IGF-1) proved to be lower in $\mathrm{CH}-\mathrm{C}$ compared to the controls. No significant differences were detected in the concentration of S-IGFBP-3 between the studied groups but the S-IGF-1/IGFBP-3 ratio in the $\mathrm{CH}-\mathrm{C}$ group was significantly lower compared to the control. H-IGFBP-3 was higher in $\mathrm{CH}-\mathrm{C}$ compared to those in the control and HCC. In HCC, lower expression of $\mathrm{H}-\mathrm{IGF}-1$ was detected compared to the control and a higher $\mathrm{H}-\mathrm{IGF}-1 / \mathrm{IGFBP}-3$ ratio compared to $\mathrm{CH}-\mathrm{C}$. A negative correlation was detected between S-IGF-1 and S-IGF-1/IGFBP-3 ratio, on the one hand, and age, grading and concentration of $\alpha$-fetoprotein (AFP) on the other, while H-IGFBP-3 was negatively correlated with $\mathrm{BMI}$ in the $\mathrm{CH}-\mathrm{C}$ group. In
\end{abstract}

Correspondence to: Professor Aldona Kasprzak, Department of Histology and Embryology, Poznan University of Medical Sciences, Święcickiego 6, 60-781 Poznań, Poland

E-mail: akasprza@ump.edu.pl

Key words: insulin-like growth factor-1, insulin-like growth factor binding protein-3, insulin-like growth factor-1/insulin-like growth factor binding protein-3 ratio, hepatitis $\mathrm{C}$ virus, hepatocellular carcinoma patients with $\mathrm{CH}-\mathrm{C}$, the $\mathrm{H}-\mathrm{IGF}-1 / \mathrm{IGFBP}-3$ ratio was higher compared to that of the S-IGF-1/IGFBP-3 ratio. The studies documented a disturbed H-IGF-1 and H-IGFBP-3 in CH-C, which may be of significance in carcinogenesis. Examination of serum concentration and tissue expression of the two proteins and, first of all, estimation of the IGF-1/IGFBP-3 ratio may provide additional (to the estimation of IGF-1 and AFP) non-invasive markers in HCV-related liver injury.

\section{Introduction}

Infection with hepatitis $\mathrm{C}$ virus (HCV) leads to chronic hepatitis in $60-80 \%$ of the patients, with the exception of individuals infected with genotype 2 in Africa, who were found to eliminate the virus more effectively ( $\sim 50 \%$ of the cases). Chronic hepatitis $\mathrm{C}(\mathrm{CH}-\mathrm{C})$ leads to liver cirrhosis in at least $20 \%$ of patients within 20 years after infection and to hepatocellular carcinoma (HCC) in $~ 25 \%$ of $\mathrm{HCV}$-infected patients $(1,2)$. Epidemiological studies showed that HCC develops in 3-6\% patients with HCV-related liver cirrhosis and in $\sim 1 \%$ of $\mathrm{HCV}$-positive patients manifesting no signs of cirrhosis (3). In HCV-related carcinogenesis, participation of viral proteins themselves used to be accentuated, including at least three $\mathrm{HCV}$ proteins: capsid protein (core, protein $\mathrm{C}$ ) and two non-structural proteins, NS3 and NS5A $(4,5)$. Such products of $\mathrm{HCV}$ genome have a direct influence on the disturbance of balance between proliferation and apoptosis of liver cells. These processes are also regulated by liver-derived growth factors, to which insulin-like growth factor (IGF)-1 and -2 belong $(6,7)$. IGF-1 is a secretory protein consisting of a single polypeptide chain with 70 amino acids, which manifests $\sim 50 \%$ sequence identity to that of insulin $(8,9)$. In the postnatal period, liver remains the main source of circulating IGF-1 and the protein is produced mainly under effect of growth hormone (GH). Secretion of IGF-1 is also affected by age, gender, genetic factors, nutrition, insulin and disease conditions (9-11). IGF-1 produced in the liver exerts mainly endocrine activity while IGF-1 synthesized by other tissues acts in a para- and/or autocrine manner $(8,9)$. Aside from IGF-1, the system consists of the receptors IGF-1R, IGF-2R, insulin receptor (IR), hybrid dimmers, and at least six high affinity insulin-like growth factor binding proteins (IGFBPs) (7). Most of the circu- 
lating IGF-1 is found in a ternary complex with IGF binding protein-3 (IGFBP-3) and the glycoprotein acid-labile subunit (ALS) (11). Binding of IGFBP-3 to IGF-1 prevents the ligand from interacting with the receptors and IGFBP-3 can modulate, both in circulation and in extracellular environment, the extent of IGF-1-dependent effects (12). IGF-1 acts primarily through the binding and the activation of IGF-1R, and ligation of IGF-1R initiates intracellular signalling cascades, involved in mitogenic, cell-survival, anti-apoptotic and transforming activities (13). The IGFBPs may also induce mitogenesis and cell migration (12). Serum concentration of IGF-1 (S-IGF-1) in childhood grows systematically, most rapidly before and during pubescence, when it attains the highest levels, reaching a plateau in early adulthood $(10,14)$. A systematic slow reduction in the IGF-1 level up to the 80th year of age is noted (15). Discordant data are available on a correlation between serum IGFBP-3 (S-IGFBP-3) and age of patients (14,16-18). Concentrations of IGF-1 and IGFBP-3 are stable during the day even if $\mathrm{GH}$, secreted in a pulsatory way, remains to be the principal factor stimulating production and secretion of the two proteins. Levels of IGF-1 are more sensitive to GH control than are the levels of IGFBP-3 (19).

A decreased serum level of both IGF-1 and IGF-2 were found to parallel progression of liver diseases, independently of their etiology (20-23). In liver cirrhosis, lower IGF-1 levels were observed in comparison to control $(24,25)$, as well as its increased concentration following anti-viral therapy (25). A continuous decline in the serum concentration of IGF-1 and IGFBP-3 was observed during progression of cirrhosis and the data correlated significantly with the Child score index (21). Other investigations documented decreased levels of IGF-1 and IGF-2 in chronic liver diseases but the positive correlation with severity of a disease was detected only for IGF-2 (26). The decreased S-IGF-1 level was more pronounced in cases with virus-associated compared to virus-negative HCCs (27). In $\mathrm{CH}-\mathrm{C}$, lowered S-IGF-1 levels correlated with severity of liver dysfunction (28) and staging (25). Other investigations found the reduction of S-IGF-1 level to precede by $\sim 9$ months the development of HCV-associated HCC (29). There are also data on elevated levels of S-IGF-1 and lowered levels of S-IGFBP-3 as compared to the control in chronic viral hepatitis (HCV or HBV) (30). Lower levels of S-IGFBP-3 were observed in liver steatosis (22), CH-C and liver cirrhosis $(18,23,28,31)$. Serum levels of IGF-1 $<30 \mathrm{ng} / \mathrm{ml}$, IGF-2 $<200 \mathrm{ng} / \mathrm{ml}$ and IGFBP-3 $<6 \mathrm{ng} / \mathrm{ml}$ indicated a negative prognosis for patients with liver cirrhosis (28). Other studies on patients with already advanced HCC demonstrated markedly lower concentrations of IGF-1 in HCC developed in the course of $\mathrm{HCV}$ infection than those noted in hepatitis B virus (HBV)-related HCC (32).

Few studies refer to the role of hepatic IGF-1 and IGFBP-3 expression in chronic hepatitis as prognostic factors related to development of HCC $(33,34)$. In the reports, descriptions of a lowered tissue expression of IGF-1 $(33,34)$ and of a tendency for an increased production of IGF-2 prevail (33). In human HCC samples, IGFBP-3 protein levels were either undetectable or low compared with non-neoplastic liver tissue examined by western blotting (35). The role of the local expression of IGF-1 and IGFBP-3 in the progression of chronic hepatitis to HCC remains unclear. The loss of autocrine/paracrine IGFBP-3 loops is thought to potentially lead to HCC tumor growth (35).
Previous results also suggest that IGFBP-3 has growthinhibitory activity which is independent of its IGF binding properties (36). Particularly little information is available on the coexistence of HCV etiology and tissue expression of IGF-1 and IGFBP-3 as prognostic factors of HCC development (34). Following our earlier studies (37), the aim of this study was to evaluate the levels of S-IGF-1 and S-IGFBP-3 and hepatic expression of both proteins in $\mathrm{CH}-\mathrm{C}$ and $\mathrm{HCC}$ samples. The ratio between IGF-1 and IGFBP-3 was also calculated.

\section{Materials and methods}

Patients and tissue material. Studies were performed on serum and liver biopsies obtained from 37 adult patients (18 men and 19 women) aged 18-63 years (mean age 36 \pm 14 years) with $\mathrm{CH}-\mathrm{C}$ (CH-C group) diagnosed at the Department of Infectious Diseases, Poznan University of Medical Sciences. The patients were referred to an anti-viral treatment and had not previously been treated. The group was recruited in 2010-2012. Infections with other hepatotropic viruses (HBV, HCMV, EBV) or other reasons of liver damage were excluded. Patients with diabetes mellitus, kidney failure or any hormone disturbances were not included in the group. HCV infection was confirmed by the presence of anti-HCV antibodies (ELISA method, HCV version 3.0 AXYM System; Abbott) and serum HCV RNA (AMPLICOR $\mathrm{HCV}^{\mathrm{TM}}$ test, version 2.0; Roche, Mannheim, Germany). Fifteen healthy volunteers (blood donors), age- and gender-matched with the cases, were used as a serum control group (mean age $34 \pm 8$ years). Plasma levels of IGF-1 were measured by ELISA method (IDS IGF-I ELISA kit; Immunodiagnostic Systems Ltd., Boldon, UK). The quantitative measurement of IGFBP-3 in serum was performed with immunoenzymetric assay (DIAsource IGFBP-3-EASIA Kit; DIAsource Immunoassays S.A., Nivelles, Belgium). Results of both tests were expressed in $\mathrm{ng} / \mathrm{ml}$. Liver biopsy and biochemical tests were performed in all cases as a routine procedure prior to antiviral therapy. Based on USG tests and $\alpha$-fetoprotein (AFP) levels, neoplastic growth (HCC) was not suspected in any patients. Written informed consent was obtained from all patients prior to liver biopsy and approval for the study was granted by the institution's Ethics Committee. The archival paraffin blocks (without serum samples) with HCC were obtained from 4 patients and tissue microarray panel ( $n=57$ ) (Cybrdi, Inc., Rockville, MD, USA). Mean age of the HCC group was $51 \pm 13$ years; 39 patients had histological grading of malignancy G2, 13 patients G3 and 9 patients G1. Only one patient from the HCC group was $\mathrm{HCV}$-positive, in the remaining patients (also in tissue microarray panel) their serological status related to $\mathrm{HCV}$ infection remained unknown.

The negative control tissue samples were obtained from livers of serologically HCV-, HBV-, HCMV- and EBV-negative organ donors and normal livers from tissue microarray panel (Cybrdi, Inc.) ( $\mathrm{n}=10)$ (mean age of the group was $50 \pm 16$ years). These normal controls were without morphological evidence of pathology. Liver biopsy specimens and all tissue controls were fixed in $10 \%$ buffered formalin, embedded in paraffin for purposes of light microscopy and immunocytochemistry.

Histopathological lesions of $\mathrm{CH}-\mathrm{C}$ patients were analyzed following the classical H\&E staining by two pathologists employing a numerical scoring system for the grading $(\mathrm{G}=0-3)$ 
Table I. Mean serum level \pm SD and range (in brackets) of IGF-1, IGFBP-3 and IGF-1/IGFBP-3 ratio in the CH-C and the control group.

\begin{tabular}{lccc}
\hline & CH-C $(\mathrm{n}=37)$ & Control $(\mathrm{n}=15)$ & P-value \\
\hline S-IGF-1 (ng/ml) & $66.18 \pm 38.99(9.22-175.66)$ & $129.38 \pm 56.29(70.62-289.72)$ & 0.0001 \\
S-IGFBP-3 (ng/ml) & $919.73 \pm 120.61(727.86-1268.34)$ & $913.48 \pm 94.97(759.26-1036.65)$ & 0.842 \\
S-IGF-1/IGFBP-3 & $0.07 \pm 0.05(0.01-0.19)$ & $0.14 \pm 0.06(0.08-0.31)$ & 0.0001 \\
\hline
\end{tabular}

SD, standard deviation; IGF-1, insulin-like growth factor-1; IGFBP-3, insulin-like growth factor binding protein-3; CH-C, chronic hepatitis C; $\mathrm{S}$, serum; P-value, level of significance.

Table II. Spearman's correlation coefficients between IGF-1, IGFBP-3 serum concentration (S) and hepatic expression (H) vs. selected clinical data in the $\mathrm{CH}-\mathrm{C}$ group.

\begin{tabular}{lcrrrrrr}
\hline & Age (years) & BMI & Staging $^{\mathrm{a}}$ & Steatosis $^{\mathrm{a}}$ & ALT (U/l) & AFP (ng/ml) & HCV RNA (IU/ml) \\
\hline S-IGF-1 (ng/ml) & $\mathbf{- 0 . 6 2 1}$ & $\mathbf{- 0 . 3 3 8}$ & -0.311 & -0.296 & $\mathbf{- 0 . 3 3 9}$ & $\mathbf{- 0 . 6 3 0}$ & $\mathbf{- 0 . 3 3 2}$ \\
H-IGF-1 (\% of reaction) & 0.058 & 0.183 & -0.268 & -0.160 & 0.134 & -0.081 & $-\mathbf{0 . 3 6 0}$ \\
S-IGFBP-3 (ng/ml) & 0.210 & 0.084 & 0.318 & 0.163 & -0.006 & 0.107 & -0.054 \\
H-IGFBP-3 (\% of reaction) & -0.173 & $\mathbf{- 0 . 4 3 3}$ & 0.062 & -0.200 & -0.056 & 0.012 & -0.092 \\
S-IGF-1/IGFBP-3 ratio & $\mathbf{- 0 . 6 0 0}$ & -0.316 & $\mathbf{- 0 . 3 4 8}$ & -0.306 & -0.301 & $\mathbf{- 0 . 6 2 6}$ & -0.307 \\
H-IGF-1/IGFBP-3 ratio & 0.313 & $\mathbf{0 . 4 7 9}$ & -0.158 & 0.242 & 0.099 & 0.019 & 0.001 \\
\hline
\end{tabular}

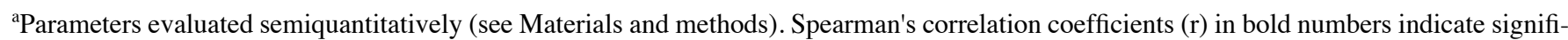
cance of the correlation at $\mathrm{P}<0.05$. IGF-1, insulin-like growth factor-1; IGFBP-3, insulin-like growth factor binding protein-3; $\mathrm{CH}-\mathrm{C}$, chronic hepatitis C; ALT, alanine aminotransferase; AST, aspartate aminotransferase; AFP, $\alpha$-fetoprotein.

and for the stage of fibrosis ( $\mathrm{S}=0-4)$ according to the METAVIR Cooperative Study Group (38). Liver steatosis was also semiquantitatively appraised, scoring 0 when no fatty degeneration was noted under a light microscope, and annotating grades 1 or 2 when, respectively, $<30 \%$ of hepatocytes or $30-70 \%$ of hepatocytes were affected (39).

Immunocytochemistry. For immunocytochemistry, $5 \mu \mathrm{m}$ sections were cut and mounted onto SuperFrost/Plus microscope slides. Monoclonal anti-human IGF-1 and IGFBP-3 antibodies (in a dilution of 1:500 and 1:100, respectively; R\&D Systems, Inc.) were employed. The studies followed the classical (strapt)avidin-biotin-peroxidase complex (ABC) technique (40), the details of which were previously described (39). In the case of IGFBP-3, microwave-oven pretreatment for antigen retrieval was used. Internal negative control reactions were based on substituting specific antibodies with normal sera of the respective species in $0.05 \mathrm{M}$ Tris- $\mathrm{HCl}, \mathrm{pH} 7.6$, supplemented with $0.1 \% \mathrm{BSA}$ and $15 \mathrm{mM}$ sodium azide.

Morphometric study using spatial visualization method. Histological slides with IGF-1 and IGFBP-3 positive immunocytochemical expression were examined under the optical Olympus BH-2 Microscope, coupled to a digital camera. Colour microscope images were recorded using x40 objective (at least 10 fields in every slide), 2,560x1,920 pixels in size using LUCIA Image 5.0 Computer Software, documenting them in jpg format on the computer hard disc. The image analysis was conducted using a technique based on spatial visualization of protein expression in microscope images, elaborated and programmed in the A4D computer software $\mathrm{C}^{++}$language (41). Results obtained in the two software for image analysis (LUCIA Image 5.0 and A4D) were exported to the format of Microsoft Excel programme. Mean surface area of positive immunocytochemical reaction for IGF-1 and IGFBP-3 per entire surface area of liver parenchyma in every patient and every group of patients was calculated, and expressed in percentage (\%), as previously described (37).

Statistical analysis. First, the parameters of descriptive statistics were calculated (arithmetic mean, standard deviation, median value, minimum and maximum values). For statistical analysis of qualitative traits we employed the MannWhitney test for unlinked samples. In cases of linked traits, Wilcoxon's test was applied. Correlations between data rows were determined with the Spearman's rank correlation index and Kruskal-Wallis test. The relationships or differences were considered significant at the significance level of $P \leq 0.05$. The statistical analysis took advantage of the Statistica PL v. 8 software.

\section{Results}

Serum concentration of IGF-1 and IGFBP-3 in the CH-C group and control. S-IGF-1 level was significantly lower in $\mathrm{CH}-\mathrm{C}$ patients compared to controls. Notably, there was no significant difference in S-IGFBP-3 level between the two examined groups. In the $\mathrm{CH}-\mathrm{C}$ group, a significantly lower 


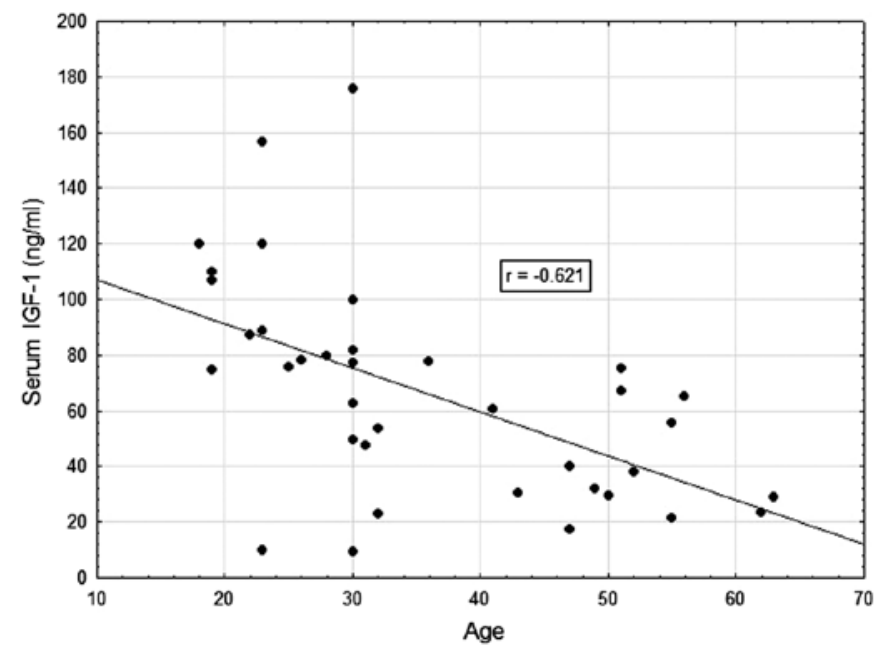

Figure 1. Negative Spearman's correlation between S-IGF-1 level and age (years) in the chronic hepatitis $\mathrm{C}$ group.

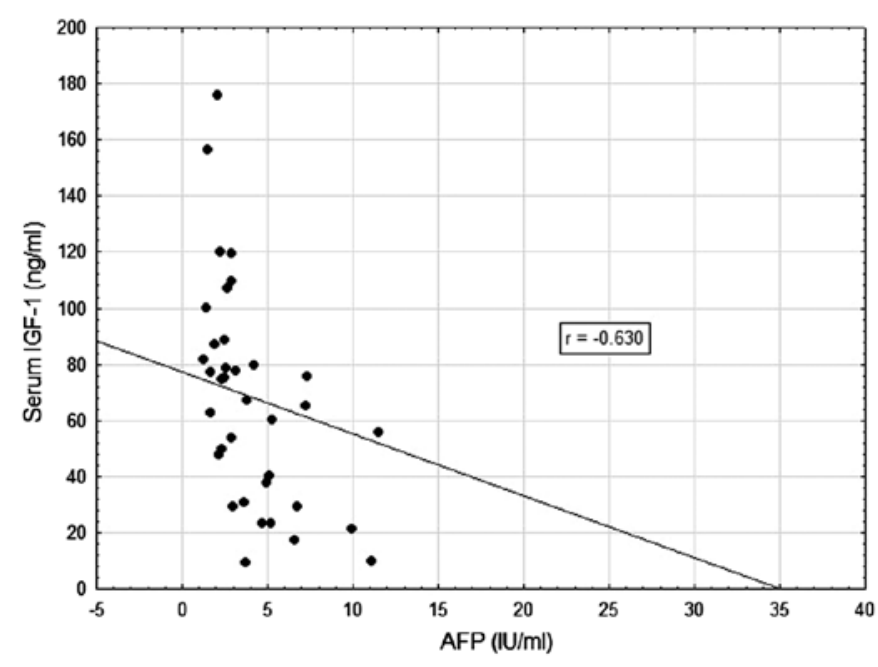

Figure 2. Negative Spearman's correlation between S-IGF-1 level and concentration of $\alpha$-fetoprotein (AFP) in the chronic hepatitis $\mathrm{C}$ group.

ratio S-IGF-1/IGFBP-3 was noted, as compared to the control group (Table I).

Serum concentration of IGF-1 and IGFBP-3 vs. clinicopathological data in the $\mathrm{CH}$-C group. In patients with $\mathrm{CH}-\mathrm{C}$, strong negative relationships were demonstrated between concentration of S-IGF-1, on the one hand, and patient age $(\mathrm{r}=-0.621$; $\mathrm{P}=0.001)$ and AFP concentration $(\mathrm{r}=-0.630 ; \mathrm{P}=0.001)$ on the other (Table II, Figs. 1 and 2). Very weak negative correlations were documented between S-IGF-1, on the one hand, and BMI ( $\mathrm{r}=-0.338 ; \mathrm{P}=0.04)$, ALT activity $(\mathrm{r}=-0.339 ; \mathrm{P}=0.04)$ and concentration of HCV RNA ( $\mathrm{r}=-0.332 ; \mathrm{P}=0.04)$ on the other (Table II). No significant correlations were detected between S-IGF-1 level, liver steatosis and staging (Table II) and other studied biochemical parameters (AST, levels of total protein, albumins, $\gamma$ globulins, total bilirubin, glucose, and HOMA-IR) (data not shown). Upon comparison of serum concentration of the two proteins (IGF-1 and IGFBP-3) using also Wilcoxon's test for various intensities of inflammation

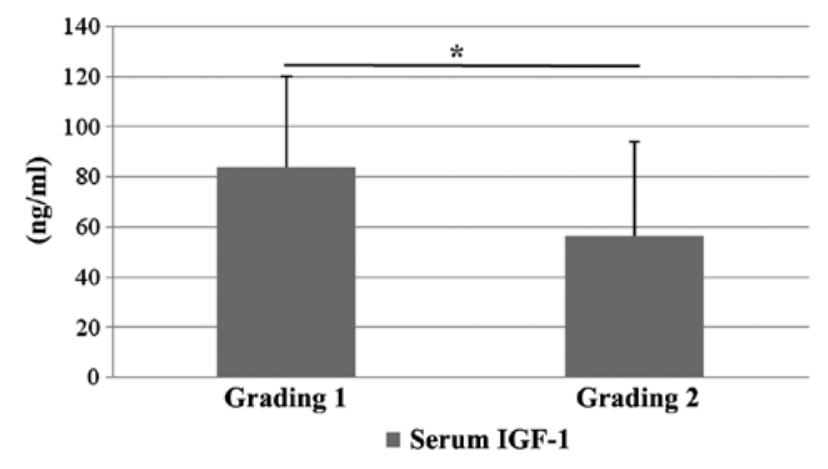

Figure 3. Comparison of S-IGF-1 concentrations in patients with chronic hepatitis $\mathrm{C}$ as related to grading. ${ }^{*} \mathrm{P}=0.03$.

(grading), a significantly lower S-IGF-1 was detected in patients with grading $2(56.56 \pm 37.43)$ as compared to patients with grading $1(84.28 \pm 36.00 ; \mathrm{P}=0.03)$ (Fig. 3). The group with grading 3 included only 3 patients and, therefore, the respective data could not be compared.

Concentration of S-IGFBP-3 in the $\mathrm{CH}-\mathrm{C}$ group failed to manifest significant relationships with any clinical or pathological variables in the patients (Table II). On the other hand, the S-IGF-1/IGFBP-3 ratio demonstrated pronounced negative correlations with: i) patient age $(\mathrm{r}=-0.600 ; \mathrm{P}=0.001)$; ii) AFP concentration $(\mathrm{r}=-0.626 ; \mathrm{P}=0.001)$; and weak correlations between iii) S-IGF-1/IGFBP-3 and liver staging ( $r=-0.348$; $\mathrm{P}=0.03$ ); and iv) a tendency for negative correlation between $\mathrm{S}-\mathrm{IGF}-1 / \mathrm{IGFBP}-3$ and steatosis $(\mathrm{r}=-0.305 ; \mathrm{P}=0.06)$ (Table II). A significantly lower S-IGF-1/IGFBP-3 ratio was detected in patients with grading $2(0.06 \pm 0.04)$ as compared to patients with grading $1(0.10 \pm 0.04 ; \mathrm{P}=0.02)$ (data not shown).

No significant correlations were detected between IGF-1/ IGFBP-3 index and the remaining clinical variables (BMI, ATL, HCV-RNA) (Table II) or with levels of total protein, albumins, $\gamma$ globulins, total bilirubin, glucose and HOMA-IR (data not shown).

Tissue expression of IGF-1 and IGFBP-3. In control livers, expression of IGF-1 was detected in the cytoplasm of almost all hepatocytes in a high power field (Fig. 4A), and IGFBP-3 was noted mainly in cells of liver sinusoids and, in lower amounts, in hepatocytes as well (Fig. 4B). In all HCV-infected patients, cytoplasmic expression of IGF-1 prevailed in hepatocytes (Fig. 4C) and cholangiocytes (Fig. 4D). IGFBP-3 was detected mainly in hepatocytes (Fig. 4E) but also in cells of liver sinusoids (Fig. 4F). In HCC cells, weak cytoplasmic expression of IGF-1 (Fig. 4G) and IGFBP-3 (Fig. 4H) were demonstrated. Mean hepatic expression of IGF-1 (H-IGF-1) in patients with $\mathrm{CH}-\mathrm{C}$ was $19.80 \pm 22.00 \%$ and it was significantly lower than that in the control $(40.81 \pm 18.53 \%)$ and HCC $(31.80 \pm 14.25 \%)$ (Fig. 5). IGFBP-3 tissue (H-IGFBP-3) expression in the $\mathrm{CH}-\mathrm{C}$ group amounted to $15.10 \pm 18.00 \%$ and it was significantly higher than that in the control group $(3.78 \pm 7.40 \%)$ and HCC (1.78 \pm 6.16$)$ (Fig. 6). The mean H-IGF-1/IGFBP-3 ratio for the $\mathrm{CH}-\mathrm{C}$ group amounted to $32.20 \pm 73.00$ and it was significantly

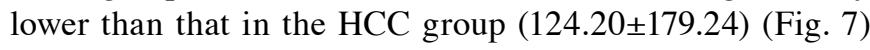
but it did not differ from that noted in the control group (95.92 \pm 185.52$)$. 

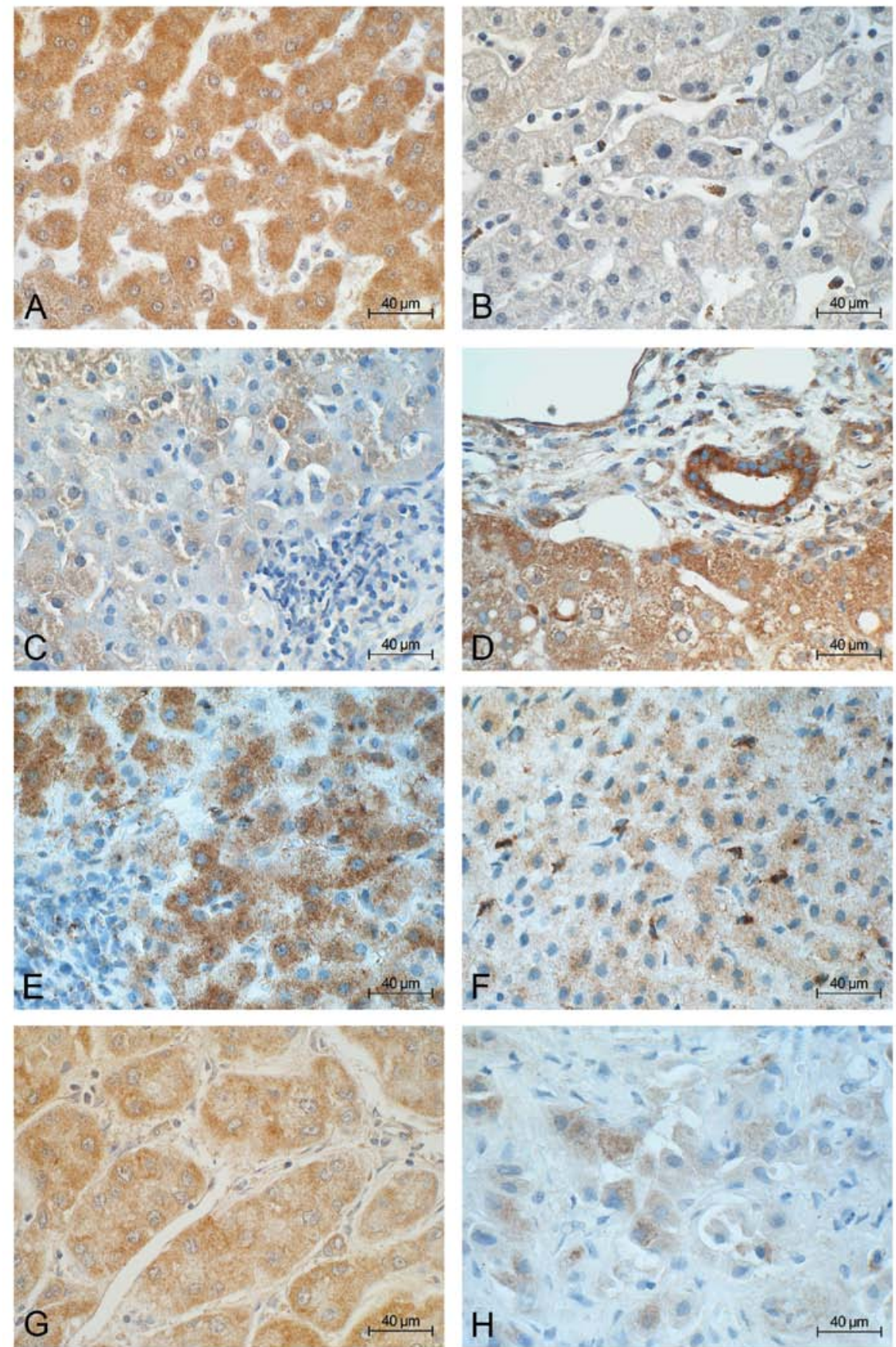

Figure 4. Insulin-like growth factor-1 (IGF-1) tissue expression in control liver samples (A); insulin-like growth factor binding protein-3 (IGFBP-3) liver expression mainly in hepatic sinusoids and in a small number of hepatocytes in the control group (B). In all hepatitis $\mathrm{C}$ virus (HCV)-infected patients, cytoplasmic expression of IGF-1 prevailed in hepatocytes (C) and cholangiocytes (D). IGFBP-3 liver expression mainly in HCV-infected hepatocytes (E), and individual hepatic sinusoidal cells (F). In hepatocellular carcinoma neoplastic cells, weak cytoplasmic expressions of IGF-1 (G) and IGFBP-3 (H) were observed. ABC technique. Hematoxylin counterstained.

Cellular expression of IGF-1 and IGFBP-3 in HCC samples. Expression of both IGF-1 and IGFBP-3 was demonstrated mainly in the cytoplasm of neoplastic cells (Fig. 4G and $\mathrm{H}$ ). Intensity of two protein expressions manifested extensive individual differences. Quantitative analysis showed that expression of IGF-1 in studied HCC samples (H-IGF-1) was reduced as compared to that in the control $(\mathrm{P}=0.05)$ (Fig. 5). Hepatic IGFBP-3 expression in HCC showed no significant differences as compared to the control $(\mathrm{P}=0.088)$ (Fig. 6). Also, no significant differences were observed between the hepatic IGF-1/IGFBP-3 ratio in this group of patients and in the control
$(\mathrm{P}=0.230)$ (Fig. 7). Results of comparative tissue expression in $\mathrm{HCC}$ samples and in $\mathrm{CH}-\mathrm{C}$ were described above (Figs. 5-7). Although it was least pronounced in grading 3 (mean of $24.64 \pm 14.14 \%$ ), expression of IGF-1 in HCC samples manifested no significant differences as compared to the expression in grading $1(33.36 \pm 16.78)$ or grading $2(33.61 \pm 13.53)$ (data not shown). Similar differences were related to H-IGFBP-3 expression, which amounted to the mean of $2.32 \pm 5.02 \%$ in grading $1,2.19 \pm 7.29$ in grading 2 and $0.17 \pm 0.29$ in grading 3, none of which were significantly different. The highest IGF-1/IGFBP-3 index was noted in grading 2 (150.06 \pm 217.65$)$, 


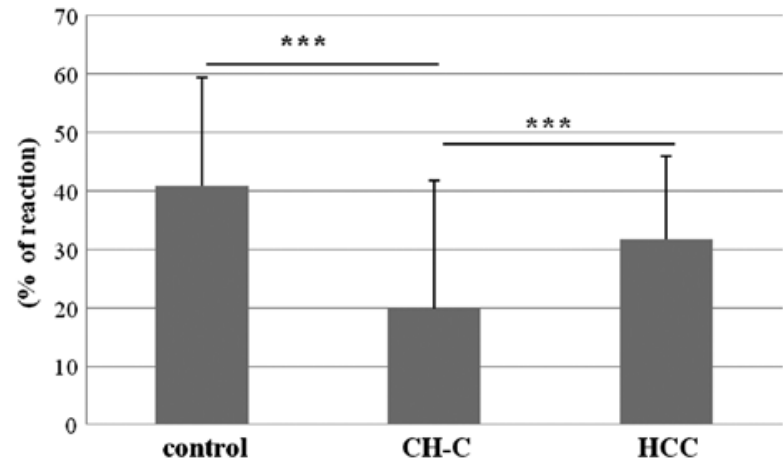

Figure 5. Mean liver expression of insulin-like growth factor-1 in control patients, patients with chronic hepatitis $\mathrm{C}(\mathrm{CH}-\mathrm{C})$ and hepatocellular carcinoma (HCC) samples. ${ }^{* * *} \mathrm{P}<0.05$. $\mathrm{P}=0.05$ between $\mathrm{HCC}$ and control.

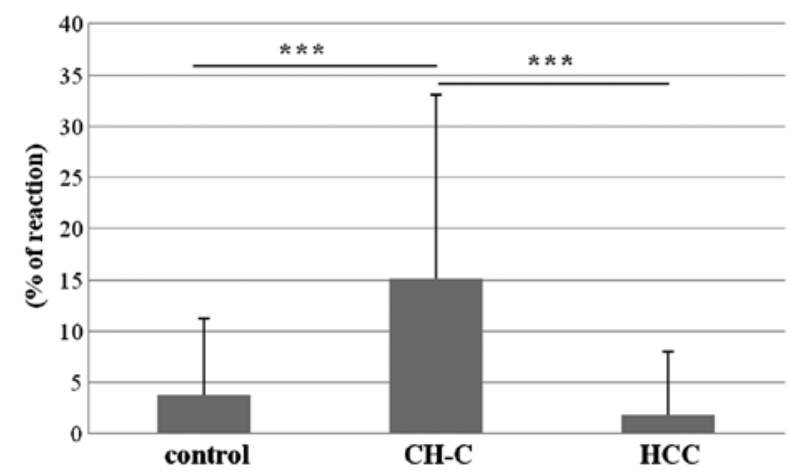

Figure 6. Mean liver expression of insulin-like growth factor binding protein-3 in control patients, patients with chronic hepatitis $\mathrm{C}(\mathrm{CH}-\mathrm{C})$ and hepatocellular carcinoma (HCC) samples. ${ }^{* * *} \mathrm{P}<0.05$.

as compared to $91.60 \pm 117.07$ in grading 1 and $83.50 \pm 57.81$ in grading 3. Statistical analysis manifested no significant differences related to the degree of histological malignancy. Also, no significant reciprocal correlation was found between expressions of H-IGF-1 and H-IGFBP-3 in HCC samples $(\mathrm{r}=0.143 ; \mathrm{P}>0.05)$ (data not shown).

Gender differences in IGF-1 and IGFBP-3 serum levels and liver expression in the $\mathrm{CH}$ - $\mathrm{C}$ group. Compared to male patients, a significantly higher concentration of S-IGF-1 was detected in women with $\mathrm{CH}-\mathrm{C}$ but no gender-related differences were detected in concentrations of S-IGFBP-3. Furthermore, no gender-related differences were revealed in tissue expressions of IGF-1 and IGFBP3. A higher S-IGF-1/IGFBP-3 index was found in women, as compared to men, in the patient group, with no gender-related differences in values of IGF-1/IGFBP-3 tissue ratio (Table III).

Reciprocal correlation between serum concentration and tissue expression of IGF-1 and IGFBP-3 in the CH-C group. No significant relationships were found between concentrations of S-IGF-1 and S-IGFBP-3 ( $\mathrm{r}=-0.172 ; \mathrm{P}>0.05)$. No significant correlations were found between concentration of S-IGF-1 and hepatic expression of the protein $(r=0.251$; $\mathrm{P}>0.005$ ) (data not shown). No significant relationships were detected between levels of S-IGF-1 and H-IGFBP-3 expression $(\mathrm{r}=0.244 ; \mathrm{P}>0.05)$. Also, no correlation was detected between

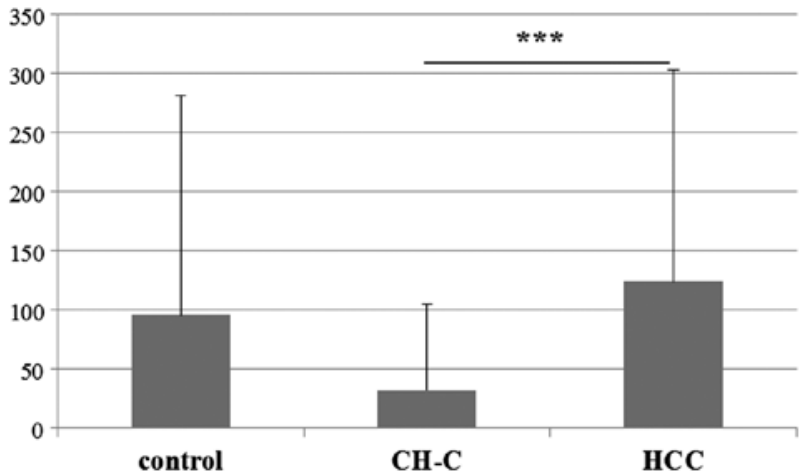

Figure 7. Mean liver expression of insulin-like growth factor-1/insulin-like growth factor binding protein-3 ratio in the control group, patients with chronic hepatitis $\mathrm{C}(\mathrm{CH}-\mathrm{C})$ and hepatocellular carcinoma (HCC) samples. ${ }^{* * * *} \mathrm{P}<0.05$

expressions of H-IGF-1 and H-IGFBP-3 ( $\mathrm{r}=0.042 ; \mathrm{P}>0.05)$ (data not shown).

Tissue expression of IGF-1 and IGFBP-3 vs. clinical data in the $\mathrm{CH}$-C group. Liver IGF-1 expression in the $\mathrm{CH}-\mathrm{C}$ group demonstrated only a weak negative correlation with serum load of HCV RNA ( $\mathrm{r}=-0.360 ; \mathrm{P}=0.04)$. Expression of H-IGFBP-3 manifested a weak negative correlation with patient BMI $(\mathrm{r}=-0.433 ; \mathrm{P}=0.01)$ (Table II). No significant correlations were detected between H-IGF-1 and H-IGFBP-3 expressions, on the one hand, and ALT, AFP, staging and steatosis (Table II) and other biochemical parameters (AST, levels of total protein, albumins, $\gamma$ globulins, total bilirubin, glucose, and HOMA-IR) on the other (data not shown). Liver IGF-1/IGFBP-3 ratio was directly related to patient $\mathrm{BMI}(\mathrm{r}=0.479 ; \mathrm{P}=0.006)$ (Table II). The remaining correlations of the index with clinicopathological data proved to be insignificant (data not shown).

In the CH-C group, the hepatic IGF-1/IGFBP-3 (32.20 \pm 73.00$)$ ratio was significantly higher than the serum IGF-1/IGFBP-3 ratio $(0.07 \pm 0.05)(\mathrm{P}=0.0001)$ (data not shown).

\section{Discussion}

In the stabilization of circulating IGF-1 levels, the factors involved include age, body nutrition, genetic factors, pregnancy dependent factors and disease conditions. The effect of gender remains insufficiently defined (11). In liver diseases, serum level of IGF-1 is thought to provide a useful marker of the organ function, independently of etiology and patient age $(20,24,42)$. In the $\mathrm{CH}-\mathrm{C}$ group, our investigations confirmed the negative correlation between concentration of S-IGF-1 and patient age described by other authors $(43,44)$. Moreover, in the $\mathrm{CH}-\mathrm{C}$ group, we demonstrated that mean S-IGF-1 concentration is higher in women as compared to men. In women and men with normal liver function, a similar situation was described by Yu et al (15). Other authors demonstrated no differences in S-IGF-1 values between men and women $(17,45)$. Reports are also available which suggest slightly lower levels in females as compared to males (11). In our patients with $\mathrm{CH}-\mathrm{C}$, serum concentration of IGFBP-3 showed no differences related to age and gender although higher concentrations of S-IGFBP-3 were detected in women as compared to those in men (17). 
Table III. Gender differences in serum levels and hepatic expression of IGF-1, IGFBP-3 and IGF-1/IGFBP-3 ratio in the CH-C group.

\begin{tabular}{llrrrrr}
\hline & Gender & $\mathrm{n}$ & Mean & SD & Min & Max \\
\hline S-IGF-1 (ng/ml) & Female & 19 & 80.85 & 42.04 & 23.35 & 175.66 \\
& Male & 18 & 50.70 & 29.21 & 9.22 & 99.95 \\
S-IGFBP-3 (ng/ml) & Female & 19 & 919.10 & 134.61 & 726.86 & 1268.34 \\
& Male & 18 & 920.35 & 107.78 & 754.03 & 1188.43 \\
H-IGF-1 & Female & 17 & 17.43 & 23.90 & 0.00 & 77.23 \\
(\% of reaction) & Male & 17 & 22.18 & 19.47 & 3.35 & 57.48 \\
H-IGFBP-3 & Female & 18 & 18.88 & 18.15 & 0.02 & 54.18 \\
(\% of reaction) & Male & 16 & 10.85 & 16.34 & 0.00 & 53.05 \\
S-IGF-1/IGFBP-3 ratio & Female & 19 & 0.09 & 0.05 & 0.02 & 0.140 \\
& Male & 18 & 0.01 & 0.03 & 0.01 & 0.19 \\
H-IGF-1/IGFBP-3 ratio & Female & 17 & 26.23 & 76.99 & 0.00 & 0.12 \\
& Male & 15 & 38.90 & 71.06 & 0.06 & 313.00 \\
\hline
\end{tabular}

IGF-1, insulin-like growth factor-1; IGFBP-3, insulin-like growth factor binding protein-3; n, number of patients; S, serum; H, hepatic; $\mathrm{SD}$, standard deviation; P-value, level of significance.

The serum ratio of IGF-1/IGFBP-3 was also higher in the women compared to the men with $\mathrm{CH}-\mathrm{C}$ in our study and value of the parameter was shown to depend on patient age. This is partially consistent with previous data on healthy adults in whom S-IGFBP3 and ratio of S-IGF-1/IGFBP-3 were age-dependent (14). The relationship between S-IGF-1 concentration and nutritional status is well recognized; in persons with $\mathrm{BMI}<21$ and $\mathrm{BMI}>29$ decreased levels of IGF-1 are noted $(11,46)$. This has been corroborated by our studies on $\mathrm{CH}-\mathrm{C}$ patients although, in this case, the negative correlation between S-IGF-1 concentration and BMI was very weak. On the other hand, concentration of S-IGFBP-3 manifested no correlation with BMI in our patients with $\mathrm{CH}-\mathrm{C}$, which is also consistent with previous literature (47).

In our studies, examination of serum IGF-1 concentration confirmed previous reports which observed lower concentrations in $\mathrm{CH}-\mathrm{C}$ or in $\mathrm{HCV}$-related liver cirrhosis, as compared to the control $(25,26,29,31,32,48)$. Patients with chronic HCV infection manifested GH insufficiency and persistent $\mathrm{GH}$ resistance of hepatocytes, which may also promote a decrease in liver production of IGF-1 (48). In patients with HCV-related cirrhosis, it was even demonstrated that the reduction in IGF-1 level preceded the diagnosis of HCC by $9.3 \pm 3.1$ months (29). In the present study, we demonstrated significantly lower concentrations of S-IGF-1 in HCV-infected patients with a more intense inflammatory activity (grading 2), as compared to patients with less advanced lesions (grading 1). On the other hand, our study is not in agreement with Lorenzo-Zúñiga et al, who showed in HCV infection that mean IGF-1 values in serum were lower in patients with advanced fibrosis compared to the other patients (25). Absence of such a relationship as related to staging and liver steatosis in our findings most probably reflects the fact that in most of our patients liver steatosis and advancement of fibrosis (staging) were insignificant. On the other hand, a highly pronounced negative correlation was found between concentrations of IGF-1 and AFP in serum of patients with $\mathrm{CH}-\mathrm{C}$. This indicates that the two markers of a potential prognostic significance coexist.

In our $\mathrm{CH}-\mathrm{C}$ group, tissue expression of IGF-1 failed to correlate with concentration of S-IGF-1. However, studies on tissue level have confirmed a significantly lower local expression of IGF-1 as compared to the control. Morali et al (33) also observed a significant reduction in hepatic production of IGF-1 in chronic hepatitis and cirrhosis, although the etiology of respective liver lesions in the studies was unknown. In another study on $34 \mathrm{HCV}$-infected patients, no significant differences were detected in expression of IGF-1 mRNA as compared to the control (34). As previously described, this study also confirmed a lower than that in the control hepatic expression of IGF-1 in HCC samples (36).

Current investigations have demonstrated no differences in concentration of S-IGFBP-3 in CH-C and in the control. No significant relationships have been detected between serum levels of IGFBP-3 and clinical data. Other studies on the significance of this component of IGF axis in chronic hepatitis were focused mainly on alcohol- or HBV-related liver injuries $(28,47)$. Although the lowered concentration of IGFBP-3 was also documented in patients with $\mathrm{CH}-\mathrm{C}$, as compared to the control $(30,31)$, no correlation was detected with the clinicopathological data (grading, staging, transaminase levels) (30) or negative correlations were demonstrated with age and AST activity, and positive correlations with serum albumin and prothrombin concentration (31).

In the present study, mean value of serum IGF-1/IGFBP-3 index was significantly lower in $\mathrm{CH}-\mathrm{C}$ patients compared to control individuals. Introduction of the parameter permitted us to additionally manifest the relatively more or less pronounced negative correlations of the parameter with several clinical data (age, grading, AFP concentration, staging). In our patients, we were not able to confirm the apparently evident coexistence 
of lowered S-IGF-1 and serum IGF-1/IGFBP-3 values and the highest IGFBP-3 levels with liver steatosis, reported earlier by other authors in their studies on isolated fatty degeneration of the liver (22) or non-alcoholic fatty liver disease and portal fibrosis (49).

In the present study, quantitative evaluation of tissue IGFBP-3 expression in HCV-infected livers demonstrated a notably significant overexpression of the protein in $\mathrm{CH}-\mathrm{C}$ patients as compared to the control and HCC patients. Expression of IGFBP-3 protein in livers of patients with $\mathrm{CH}-\mathrm{C}$ has been demonstrated mainly in hepatocytes while in a normal liver, expression of IGFBP-3 has been demonstrated mainly in Kupffer cells and in portal venous and sinusoidal endothelium, in line with observations of other authors (50). Previous studies in hepatocytes of a normal or cirrhotic human liver observed gene expression of three IGF-1 binding proteins (IGFBP-1, -2 and -3). However, parallel estimations of the three protein concentrations in serum of the patients detected lowered concentrations of IGFBP-3 in cirrhotic liver, as compared to the control (51). The increased local expression of IGFBP-3 in the studied patients with $\mathrm{CH}-\mathrm{C}$ and the higher hepatic IGF-1/IGFBP-3 index, in comparison to serum IGF-1/IGFBP-3 ratio may suggest a disturbed release of IGFBP-3 from HCV-infected cells. Since no significant correlations have been detected between H-IGFBP-3 and clinical data (except for the weak negative correlation with BMI), the role of local IGFBP-3 overexpression in patients with $\mathrm{CH}-\mathrm{C}$ requires further studies. In HCC samples, we demonstrated a high value of tissue IGF-1/IGFBP-3 index, a significantly higher one than that detected in the $\mathrm{CH}-\mathrm{C}$ group. By contrast, Mattera et al detected an augmented serum IGF-1/IGFBP-3 index in patients with HCC, as compared to patients with liver cirrhosis (52). No reciprocal relationships were found between serum concentration and hepatic expression of either IGF-1 or IGFBP-3 in our CH-C group.

In conclusion, we noted lowered serum level of IGF-1 in $\mathrm{CH}-\mathrm{C}$ as compared to controls. The lowered concentration of S-IGF-1 was linked to an increased inflammatory activity (grading). Tissue expression of IGF-1 was also lower in CH-C, and that of IGFBP-3 protein was increased as compared to healthy liver. In HCC samples, a decreased liver expression of IGF-1 was observed as compared to the control and a higher hepatic ratio of IGF-1/IGFBP-3, but only as compared to the $\mathrm{CH}-\mathrm{C}$ group. Considering the serum concentration of both studied proteins, concentrations of S-IGF-1 in particular may be accepted as a suitable marker of liver injury in $\mathrm{CH}-\mathrm{C}$. Moreover, the studies suggest that inflammatory lesions induced by chronic HCV infection result in a lowered hepatic production of IGF-1, with the resulting decrease in serum IGF-1 concentration. A lowered concentration of S-IGF-1 and H-IGF-1 coexists with other exponents of liver injury in HCV infection. Apart from IGF-1, evaluation of serum IGF-1/IGFBP-3 ratio provides another index allowing to evaluate hepatic function. An increased hepatic expression of IGFBP-3 with no parallel increase in concentration of IGFBP-3 in sera of patients with CH-C may point to a blocked release of IGFBP-3 to circulation as well as to a potential autocrine/paracrine role of the protein in HCV infection. The results indicate a disturbed functioning of IGF axis in $\mathrm{HCV}$ infection. Apart from IGF-1 alone and AFP, determination of serum IGF-1/IGFBP-3 ratio may serve as an additional noninvasive marker of a progressive liver injury.

\section{Acknowledgements}

The present study was supported by a grant from the Ministry of Education and Science, Warsaw, Poland (no. NN401009437).

\section{References}

1. Fattovich G, Stroffolini T, Zagni I and Donato F: Hepatocellular carcinoma in cirrhosis: incidence and risk factors. Gastroenterology 127: S35-S50, 2004.

2. Rehermann B and Nascimbeni M: Immunology of hepatitis $B$ virus and hepatitis $C$ virus infection. Nat Rev Immunol 5: 215-229, 2005.

3. Colombo M: Hepatitis C virus and hepatocellular carcinoma. Semin Liver Dis 19: 263-269, 1999.

4. Anzola M: Hepatocellular carcinoma: role of hepatitis B and hepatitis $\mathrm{C}$ viruses proteins in hepatocarcinogenesis. J Viral Hepat 11: 383-393, 2004.

5. Kasprzak $A$ and Adamek A: Role of hepatitis $C$ virus proteins (C, NS3, NS5A) in hepatic oncogenesis. Hepatol Res 38: 1-26, 2008.

6. Alexia C, Fallot G, Lasfer M, Schweizer-Groyer G and Groyer A: An evaluation of the role of insulin-like growth factors (IGF) and of type-I IGF receptor signalling in hepatocarcinogenesis and in the resistance of hepatocellular cells against drug-induced apoptosis. Biochem Pharmacol 86: 1003-1015, 2004.

7. Kasprzak A and Adamek A: The insulin-like growth factor (IGF) signaling axis and hepatitis $C$ virus-associated carcinogenesis (Review). Int J Oncol 41: 1919-1931, 2012.

8. Daughday WH and Rotweien P: Insulin-like growth factors I and II: peptide, messenger ribonucleic acid, and gene structures, serum and tissue concentrations. Endocr Rev 10: 68-91, 1989.

9. Zarilli R, Bruni CB and Riccio A: Multiple levels of control of insulin-like growth factor gene expression. Mol Cell Endocrinol 101: R1-R14, 1994.

10. Juul A, Bang P, Hertel NT, et al: Serum insulin-like growth factor-I in 1030 healthy children, adolescents, and adults: relation to age, sex, stage of puberty, testicular size, and body mass index. J Clin Endocrinol Metab 78: 744-752, 1994.

11. Brabant $G$ and Wallaschofski $H$ : Normal levels of serum IGF-I: determinants and validity of current reference ranges. Pituitary 10: 129-133, 2007.

12. Kostecka Y and Blahovec J: Insulin-like growth factor binding proteins and their functions (minireview). Endocr Regul 33: 90-94, 1999.

13. Le Roith D, Bondy C, Yakar S, Liu JL and Butler A: The somatomedin hypothesis: 2001. Endocr Rev 22: 53-74, 2001.

14. Elmlinger MW, Kühnel W, Weber MM and Ranke MB: Reference ranges for two automated chemiluminescent assays for serum insulin-like growth factor I (IGF-I) and IGF-binding protein 3 (IGFBP-3). Clin Chem Lab Med 42: 654-664, 2004.

15. Yu H, Mistry J, Nicar MJ, Khosravi MJ, Diamandis A, van Doorn $J$ and Juul A: Insulin-like growth factors (IGF-I, free IGF-I, and IGF-II) and insulin-like growth factor binding proteins (IGFBP-2, IGFBP-3, IGFBP-6, and ALS) in blood circulation. J Clin Lab Anal 13: 166-172, 1999.

16. Juul A, Dalgaard P, Blum WF, et al: Serum levels of insulinlike growth factor (IGF)-binding protein-3 (IGFBP-3) in healthy infants, children, and adolescents: the relation to IGF-I, IGF-II, IGFBP-1, IGFBP-2, age, sex, body mass index, and pubertal maturation. J Clin Endocrinol Metab 80: 2534-2542, 1995.

17. Mattsson A, Svensson D, Schuett B, Osterziel KJ and Ranke MB: Multidimensional reference region for IGF-I, IGFBP-2 and IGFBP-3 concentrations in serum healthy adults. Growth Horm IGF Res 18: 506-516, 2008.

18. Raslan HM, Elhosary Y, Ezzat WM, Rasheed EA and Rasheed MA: The potential role of insulin-like growth factor 1, insulin-like growth factor binding protein 3 and bone mineral density in patients with chronic hepatitis C virus in Cairo, Egypt. Trans R Soc Trop Med Hyg 104: 429-432, 2010.

19. Blum WF, Albertsson-Wikland K, Rosberg S and Ranke MB: Serum levels of insulin-like growth factor I (IGF-I) and IGF binding protein 3 reflect spontaneous growth hormone secretion. J Clin Endocrinol Metab 76: 1610-1616, 1993. 
20. Wu JC, Daughaday WH, Lee SD, et al: Radioimmunoassay of serum IGF-I and IGF-II in patients with chronic liver diseases and hepatocellular carcinoma with or without hypoglycemia. J Lab Clin Med 112: 589-594, 1988.

21. Kratzsch J, Blum WF, Schenker E and Keller E: Regulation of growth hormone $(\mathrm{GH})$, insulin-like growth factor (IGF) I, IGF binding proteins $-1,-2,-3$ and $\mathrm{GH}$ binding protein during progression of liver cirrhosis. Exp Clin Endocrinol Diabetes 103: 285-291, 1995.

22. Völzke H, Nauck M, Rettig R, Dörr M, Higham C, Brabant G and Wallaschofski $\mathrm{H}$ : Association between hepatic steatosis and serum IGF1 and IGFBP-3 levels in a population-based sample. Eur J Endocrinol 161: 705-713, 2009.

23. Rehem RN and El-Shikh WM: Serum IGF-1, IGF-2 and IGFBP-3 as a parameters in the assessment of liver dysfunction in patients with hepatic cirrhosis and in the diagnosis of hepatocellular carcinoma. Hepatogastroenterology 58: 949-954, 2011.

24. Vyzantiadis T, Theodoridou S, Giouleme O, Harsoulis P, Evgenidis $\mathrm{N}$ and Vyzantiadis A: Serum concentrations of insulinlike growth factor-I (IGF-I) in patients with liver cirrhosis. Hepatogastroenterology 50: 814-816, 2003.

25. Lorenzo-Zúñiga V, Bartolí R, Masnou H, Montoliu S, Morillas RM and Planas R: Serum concentration of insulin-like growth factor-I (igf-I) as a marker of liver fibrosis in patients with chronic hepatitis C. Dig Dis Sci 52: 3245-3250, 2007.

26. Nikolić JA, Todorović V, Bozić M, et al: Serum insulin-like growth factor (IGF)-II is more closely associated with liver disfunction than is IGF-I in patients with cirrhosis. Clin Chim Acta 294: 169-177, 2000.

27. Stuver SO, Kuper H, Tzonou A, Lagiou P, Spanos E, Hsieh CC, Mantzoros $\mathrm{C}$ and Trichopoulos D: Insulin-like growth factor 1 in hepatocellular carcinoma and metastatic liver cancer in men. Int J Cancer 87: 118-121, 2000.

28. Wu YL, Ye J, Zhang S, Zhong J and Xi RP: Clinical significance of serum IGF-I, IGF-II and IGFBP-3 in liver cirrhosis. World J Gastroenterol 10: 2740-2743, 2004.

29. Mazziotti G, Sorvillo F, Morisco F, et al: Serum insulin-like growth factor I evaluation as a useful tool for predicting the risk of developing hepatocellular carcinoma in patients with hepatitis $\mathrm{C}$ virus-related cirrhosis: a prospective study. Cancer 95: 2539-2545, 2002.

30. Okan A, Cömlekçi A, Akpinar H, Okan I, Yeşil S, Tankurt E and Simsek I: Serum concentration of insulin-like growth factor-I and insulin-like growth factor binding protein-3 in patients with chronic hepatitis. Scand J Gastroenterol 35: 1212-1215, 2000.

31. Raslan H, Ezzat W, Ahmed M and Rasheed E: Insulin growthfactor-1 and insulin-like growth factor binding protein-3 in Egyptian patients with chronic hepatitis C. Arch Med Sci 3: 46-51, 2007.

32. Su WW, Lee KT, Yeh YT, Soon MS, Wang CL, Yu ML and Wang SN: Association of circulating insulin-like growth factor 1 with hepatocellular carcinoma: one cross-sectional correlation study. J Clin Lab Anal 24: 195-200, 2010.

33. Morali G, Shitrit AB,Eran M,FreierS, Reinus Cand Braverman D Hepatic production of insulin-like growth factors in normal and diseased liver. Hepatogastroenterology 52: 1511-1515, 2005.

34. Stefano JT, Correa-Giannella ML, Ribeiro CMF, Alves VAF, Massarollo PCB, Machado MCC and Giannella-Neto D: Increased hepatic expression of insulin-like growth factor-I receptor in chronic hepatitis C. World J Gastroenterol 28: 3821-3828, 2006.

35. Huynh H, Chow PKH, Ooi LLP and Soo KC: A possible role for insulin-like growth factor-binding protein-3 autocrine/paracrine loops in controlling hepatocellular carcinoma cell proliferation. Cell Growth Differ 13: 115-122, 2002.

36. Clemmons DR: Insulin-like growth factor binding proteins and their role in controlling IGF actions. Cytokine Growth Factor Rev 8: 45-62, 1997.
37. Kasprzak A, Adamek A, Przybyszewska W, et al: Expression of IGF-1 and viral proteins (C, NS3, NS5A) in the livers of patients with chronic HCV infection. Adv Clin Exp Med 20: 263-273, 2011.

38. Bedossa $\mathrm{P}$ and Poynard T: An algorithm for the grading of activity in chronic hepatitis C. The METAVIR Cooperative Study Group. Hepatology 24: 289-293, 1996.

39. Kasprzak A, Adamek A, Biczysko W, et al: Intracellular expression of the proliferative marker Ki-67 and viral proteins (NS3, NS5A and C) in chronic, long lasting hepatitis C virus (HCV) infection. Folia Histochem Cytobiol 45: 357-366, 2007.

40. Hsu SM, Raine L and Fanger H: Use of avidin-biotin-peroxidase complex $(\mathrm{ABC})$ in immunoperoxidase techniques: a comparison between $\mathrm{ABC}$ and unlabeled antibody (PAP) procedures. J Histochem Cytochem 29: 577-580, 1981.

41. Kaczmarek E and Strzelczyk R: From two to three-dimensional visualisation of structures in light and confocal microscopy - applications for biomedical studies. In: Current Issues on Multidisciplinary Microscopy Research and Education. Mendez-Vilas A, Labajos-Broncano L (eds). FORMATEX microscopy book series no. II Formatex Research Centre, Badajoz, pp289-295, 2005.

42. Mahdy KA, Ahmed HH, Mannaa F and Abdel-Shaheed A: Clinical benefits of biochemical markers of bone turnover in Egyptian children with chronic liver diseases. World J Gastroenterol 13: 785-790, 2007.

43. Aimaretti G, Boschetti M, Corneli G, et al: Normal agedependent values of serum insulin growth factor-I: results from a healthy Italian population. J Endocrinol Invest 31: 445-449, 2008.

44. Andreassen M, Nielsen K, Raymond I, Kristensen L $\varnothing$ and Faber J: Characteristics and reference ranges of insulin-like growth factor-I measured with a commercially available immunoassay in 724 healthy adult Caucasians. Scand J Clin Lab Invest 69: 880-885, 2009

45. Rosario PW: Normal values of serum IGF-1 in adults: results from a Brazilian population. Arq Bras Endocrinol Metabol 54: 477-481, 2010.

46. Holmes MD, Pollak MN and Hankinson SE: Lifestyle correlates of plasma insulin-like growth factor I and insulin-like growth factor binding protein 3 concentrations. Cancer Epidemiol Biomarkers Prev 11: 862-867, 2002.

47. Colakoğlu O, Taskiran B, Colakoğlu G, Kizilda ̆ S, Ari Ozkan F and Unsal B: Serum insulin like growth factor-1 (IGF-1) and insulin growth factor binding protein-3 (IGFBP-3) levels in liver cirrhosis. Turk J Gastroenterol 18: 245-249, 2007.

48. Plöckinger U, Krüger D, Bergk A, Weich V, Wiedenmann B and Berg T: Hepatitis-C patients have reduced growth hormone $(\mathrm{GH})$ secretion which improves during long-term therapy with pegylated interferon-alpha. Am J Gastroenterol 102: 2724-2731, 2007.

49. Ichikawa T, Nakao K, Hamasaki K, et al: Role of growth hormone, insulin-like growth factor 1 and insulin-like growth factor-binding protein 3 in development on non-alcoholic fatty liver disease. Hepatol Int 1: 287-294, 2007.

50. Arany E, Afford S, Strain AJ, Winwood PJ, Arthur MJ and Hill DJ: Differential cellular synthesis of insulin-like growth factor binding protein-1 (IGFBP-1) and IGFBP-3 within human liver. J Clin Endocrinol Metab 79: 1871-1876, 1994.

51. Ross RJM, Chew SL, D'Souza Li L, et al: Expression of IGF-I and IGF-binding protein genes in cirrhotic liver. J Endocrinol 149: 209-216, 1996.

52. Mattera D, Capuano G, Colao A, Pivonello R, Manguso F, Puzziello A and D'Agostino L: Increased IGF-I:IGFBP-3 ratio in patients with hepatocellular carcinoma. Clin Endocrinol (Oxf) 59: 699-706, 2003. 